\title{
A Study of Limits, Ignorance, and Reading Practices: Community Service-Learning as an Exercise in the Vision of Queer Pedagogy
}

\author{
Jordan Sifeldeen
}

\begin{abstract}
Theories and practices of community service-learning (CSL) have implicated it in a broad project of confronting the unthinkability of privilege and difference, the culturally situated, political nature of knowledge, and the dialogical, transformative potential of reading. I argue that this understanding of CSL largely aligns in vision, directives, and prospects with an exercise in queer pedagogy. With its critical inquiry into pedagogical practice informed by queer theory, Deborah Britzman's triangulated queer pedagogy not only shares productive theoretical ground with CSL, but can also be seen to inform, enhance, and develop the academic role of service-learning as a methodology of teaching and learning. Through its development in academic institutions in Canada, CSL should look to queer theory's established lexicon in order to take up precise, thickly descriptive, exoteric language which reflects the two fields' productive commonalities. Furthermore, where CSL literature often identifies as volunteerism, internship, and experiential learning, queer pedagogy ascribes deep transformative potential to its approach—a perspective and a potential often undervalued by practitioners of CSL. Finally, a bringing together of community service-learning and queer pedagogy illustrates the need in service-learning literature for an approach to systematic archiving which more closely adheres to the field's emphasis on the creation of deeply reflective and creative academic work.
\end{abstract}

KEYWORDS community service-learning; queer pedagogy; queer theory; archiving

"... and I suddenly became aware of myself as the victim of a prettified education. I had been taught that knowledge is simple and uncertainty is complicated; that simple truths were safe and felt good."

\section{-Anonymous}

In its project to question, reimagine, and reappropriate traditional teaching and learning practices, queer pedagogy has established a young, evolving, diverse archive of theoretical literature. Deborah Britzman (1995) articulates a triangulated queer pedagogy that is centrally grounded in a study of limits, a study of ignorance, and a study of reading practices. Britzman`s queer pedagogy is one which consistently confronts the unthinkability of difference, the complexity and situated-ness of knowledge, and the dialogical nature of reading. In this way, it mirrors both the directives and the potentialities of community service-learning. Shared 
between a vision of service-learning and a vision of queer pedagogy is an understanding of identities as constantly constructed, truth as complex/ambiguous, and reading and reflecting as having transformative potential for individuals and their beliefs. Furthermore, both disciplines take interrogating and resisting the politics of traditional educational paradigms (i.e., powerdisparate consumer models which posit teaching and learning as the exclusive and mutually distinct work of teachers and students, respectively) as central to both their educational content and method. I maintain not only that queer pedagogy and community service-learning largely align in their goals, vision, and project, but also that existing literature on queer pedagogy can inform and enhance understandings of the academic and methodological value of community service-learning in the future. In this paper, I will argue that community service-learning, as a pedagogical method grounded in theory, can and should look to queer pedagogy's lexicon, discourses of self-identification, and potential for archiving with the aim of both expanding its theoretical foundations and developing as a methodology.

In discussing and explicating a queer pedagogy, it is important to draw a distinction between a pedagogy of queer inclusion/tolerance and a queering of pedagogy itself, fundamentally a distinction between content and methodology, respectively. A pedagogy of queer inclusion and tolerance is a largely politically grounded project which aims to promote specifically queer- or gender-themed content in education. Pedagogies of queer inclusion establish LGBT visibility and representation in education as central. This approach, however, can broadly be seen to actually work against the project of queer pedagogy by propagating the "normative tolerant" and the "tolerated other" as the only available subject positions (Britzman, 1995). Incorporating queer/LGBT content simply for the goal of inclusion or to validate and catalogue identities may satisfy a discourse of tolerance or political tokenism, but it does not entail the reappropriation of teaching and learning practices themselves for which a queer pedagogy advocates. For Britzman (1995), pedagogical systems aimed at promoting tolerance of queer content and individuals fail to facilitate conceptions of identities as products of identifications; Britzman instead aims to promote a refashioning of identity "as more than a limit of attitude" (p. 160). Counter to their aims, pedagogies of inclusion can work on a deeper level to instead propagate new forms of exclusivity (Britzman, 1995, p. 160).

In contrast, queer pedagogy as a methodological project seeks not to incorporate queer/ LGBT content into contemporary teaching practices and curricula; instead, it aims to take up teaching practices themselves from a perspective of queer theory, questioning their structure and function as manufacturers of normalcy (Luhmann, 1998). Queer pedagogy refers to a theory and practice of teaching that reimagines the experience of learning, questions takenfor-granted assumptions about knowledge acquisition, and works to subvert political and ideological systems of oppression (Berlant et al., 1994). While it arises from inquiries into education by queer theorists, centrally, a queer pedagogy need not relate to issues of queerness, gender studies, or even the social sciences. Queer does not implicate the identity of the theorist nor the reader; rather, it predicts the precariousness of the theorized and the read (Britzman, 1995). As such, it is possible to reimagine the teaching of any discipline, skill, or system of thought in a queer way, from women's studies to biology to blacksmithing. 


\section{On the Study of Limits}

When referring to a study of limits, Britzman (1995) refers to a move in queer pedagogy to actively explore "where thought stops"—an attempt to deconstruct the discourses and ideologies that allow certain ideas to be valorized as cultural imperatives that are intrinsically factual, while allowing others to be dismissed as irrelevant. Britzman (1995) argues that "queer theory proposes to examine differential responses to the conditions of identities on terms that place as a problem the production of normalcy and on terms that confound the intelligibility that produces the normal as the proper subject" (p. 160). A fundamental pillar of queer pedagogy is an understanding that the unthinkable, unintelligible "other" both instantiates the possibility for self-identification and serves a pedagogical role in the production of normalcy. In other words, our identities are formed, in part, upon a legacy of pedagogical processes in which we learn about what we are not. The ideologically unproblematic self rests precariously upon unthinkably problematic "others." In elaborating the interrelated nature of queer pedagogy and community service-learning, unthinkability illuminates new, deeper complexity in literature addressing privilege, specifically as unforeseen understandings of privilege have been shown to come out of experiential learning in service-learning placements (Dunlap et al., 2007).

For Peggy McIntosh (1998), institutionalized privilege is unthinkable to those who benefit from it. From the perspective of queer pedagogy, this unthinkability comes out of the struggle of confronting that which we "cannot bear to know" (Britzman, 1995, p. 156), or the "unmarked criteria" of relevance that have shaped what our societies and subjects have shut out or ignored in order to be able to think the way they do (1995, p. 156). By systematically working to establish whiteness, maleness, and heterosexuality as normative subject positions, traditional education systems (i.e., those explicitly and implicitly uncritical of systemic privilege) teach whites, males, and heterosexuals to be oblivious to their own privilege, and furthermore imbue these subject positions with a degree of ideological and political neutrality and objectivity (McIntosh, 1988).

Dominant pedagogies tend to communicate racism and sexism as disadvantaging features of society that negatively discriminate against minorities, but the concept of unthinkability becomes salient when we frame racism and sexism simultaneously as systems of privilege for those who benefit. McIntosh (1988) describes in detail the ways in which her male colleagues in a Women's Studies department rationalized their positions when presented with the previously unthinkable concept of male privilege: even when conceding that broader systems of privilege exist that advantage men over women, they tended to deny that these systems had any effect on their personal lives or careers (p. 3). Still others accepted that, while some individual theorists may have been male-oriented or misogynistic, broader cultural discourses are more likely to put the sexes on equal footing (McIntosh, 1988, p. 3), or at least that the privileging role of sexism only partially accounts for the disparate power relations between the sexes throughout history (McIntosh 1988, p. 3). Though separated from theoretical work explicitly grounded in queer pedagogy, McIntosh's theorizing of white privilege and male privilege directly ties to queer theories of teaching which address the production of normalcy, the process of 
fashioning "normal" as an embodied subject position, and the nature of privilege (specifically as propagated by the ignorance of the privileged) (Smith, 2013; Britzman, 1995; Whitlock, 2010).

Centrally, McIntosh's theory of privilege, though canonical in community service-learning literature, can be deconstructed and analyzed productively using the established lexicon of queer theory. By understanding white privilege and male privilege as universalizing discourses which confront collective limits to thought, McIntosh can be seen as a theorist who makes "thinkable" the socially and institutionally unidentified truth of privilege; in our reading of McIntosh, we can gain precise language through which the process of knowing becomes real. As mentioned earlier, a central and vital pedagogical benefit of community service-learning is its ability to make students aware of the privileges they have enjoyed but have been trained to disregard throughout their lives. This realization, coming out of experiential learning, segues and is supplemented by deep and diverse literature on male privilege, white privilege, and heterosexual privilege coming out of queer theory. Where community service-learning thrives (giving students a jarring, pedagogically-significant experience that illuminates their privilege), queer theory supplements, expounds, and particularizes (naming this privilege and giving it a theoretical library and lexicon).

On a larger scale, the points of congruence that community service-learning shares with queer pedagogy can allow CSL to expand and develop its lexicon. In their communal project to question teaching practices, uproot and undermine presumed claims to certainty, and embrace the learning process as unclean, complicated, and always mediated, queer pedagogy and community service-learning have deep theoretical ties that can engage with each other dialogically to establish productive common lexical ground.

\section{On the Study of Ignorance}

As a study of ignorance, queer pedagogy brings to light the theoretical pitfalls of traditional teaching and learning systems with which community service-learning consistently negotiates, particularly in its self-proclaimed "underside" (Jones, 2002). Specifically, where service-learning notes the inability of some students to "get it" (Jones, 2002, p. 14), queer pedagogy critically unpacks the experiences of learning such that the existence of a singular, uncomplicated "it" to "get" becomes problematic in its own right. Community service-learning, in turn, provides its own set of academically rich, thick experiences particularly conducive to the sorts of critical analysis and ways of thinking that are central to queer pedagogy.

For the purposes of comparing community service-learning and queer pedagogy, ignorance here refers to both the ignorance entailed by a conception of knowledge as static, unmediated, and unambiguous, as well as a conception of knowledge as intrinsically anti-discriminatory and positively correlated with (if not directly predicative of) particular positive outcomes on an individual and societal level (Kirk, 2008).

Broader discourses of queer theory have largely informed understandings of knowledge and learning within the theoretical realm of queer pedagogy. The queer theory movement has demonstrated itself not only to be tolerant of ambiguity, contradiction, and disagreement, 
but also to see these instances as sites of productive meaning making. On the whole, queer pedagogy and queer theory tend to differentiate themselves in their desire to unsettle takenfor-granted conventions and systems of knowledge by always understanding them as situated within the societal production of normalcy, and by conceptualizing knowledge and ignorance not as opposites, but as mutually informing and implicating one another (Britzman, 1995; Hall, 2007). For theorists of queer pedagogy, knowledge is always cultural, textual, and ambiguous (Britzman, 1995). Where traditional educational systems tend to see these features as unthinkable, unteachable, or problematic, queer pedagogical theory takes up ambiguity and bias as productive in revealing the creation of truths through discourse.

Canadian universities have taken up similar understandings of learning in their own community service-learning literature, citing the importance of "critical thinking. . . in an increasingly complex world" (Queen's University, 2014), and improving "ability to handle ambiguity" as a specific program goal (University of Alberta, 2014). In many ways, this mirrors the broader theory and objectives of service-learning programs and ideals. For some community service-learning theorists, an ideal service-learning experience embodies many of the theoretical features of queer pedagogy, including an "uprooting of certainty" (Rutherford, 1990) and an "agitated pedagogy" (Himley, 2004). Himley's agitated pedagogy takes up ambiguity and theoretical "noise" (p. 434) as crucial, valuable, and distinctive to servicelearning in a similar manner to queer pedagogy and Canadian universities on the whole.

Furthermore, Butin's (2010) exploration of the antifoundational approach to servicelearning embraces the ambiguity and situated-ness of truths previously explicated by theorists of queer pedagogy, including the desire "to foster doubt concerning the normalcy and neutrality of our seemingly commonsensical view of the world," the acceptance that "there is no neutral, objective, or contentless 'foundation' by which we can ever know the 'truth' unmediated by our particular condition" (p. 12), and the awareness of "the always contingent character of our assumptions and truths" (p. 13). Moving further, Butin (2010) even argues that the role of antifoundational service-learning, much like the role of a queer pedagogy, is "committed to denying us the (seeming) firmness of our commonsensical assumptions" (p. 13). For Butin, the end goal of an antifoundational service-learning experience should not be to close off a discussion with the assumption of knowledge, but to have the discussion remain contentious, problematic, and open to a long-form learning experience.

Britzman (1995) argues in her theory of queer pedagogy that, in order to truly retain a queer understanding of learning, one must detach from the idea that "information discourse, in and of itself, is anti-discriminatory" - that knowledge necessarily correlates with proper behavior in subjects (p. 160). Particularly from an antifoundational perspective, community service-learning, in bringing together theoretical work and lived experience, also grapples with the assumption that "good knowledge leads to good conduct and that receiving information is no problem for the learner" (Britzman, 1995, p. 160). Jones (2002) discusses this issue directly in relation to community service-learning material, acknowledging the various ways in which seemingly anti-discriminatory pedagogy worked instead to alienate students from the theoretical perspectives with which they engaged. For Jones (2002), "the underside of service 
learning is not just about students' inability to 'get it' . . or to process new experience, but also about our [instructors'] inability to anticipate comments, understand where students are in their developmental process, and acknowledge complex issues" (p. 14). In other words, to the extent that service-learning is an embodied experience rich with ambiguities and sites of tension, it is also an experience which brings to light our ignorance as participants. It is not necessarily possible for service-learning (or queer) pedagogies to assume that students will act with proper tolerance or open-mindedness simply by providing them with information, or even with experiences.

The ways in which knowledge, ignorance, and learning are conceptualized within community service-learning mirror not only the structures of queer pedagogy, but also the transformative potential. However, where theorists of queer pedagogy have identified their movement as one of world-building, revolution, and a reimagining and restructuring of the academy, community service-learning, despite equally vast potential to promote change, has self-identified variously as volunteerism, work experience, internship, or community building. Reading community service-learning as a supplement to traditional learning grounded in volunteerism, though ostensibly positive, is too limiting; a movement need only be limited by its vision, and where the discourses of queer theory have tended to be expansive, ambitious, and radical, much discourse in community service-learning has been restricted. Community service-learning is not "your learning but better" - it is an entirely new way of imagining how learning might work. Community service-learning, while academic, is also revolutionary.

\section{On the Study of Reading Practices}

As a study of reading practices, queer pedagogy illuminates and informs the ways in which community service-learning students engage in critical readings of both academic texts and their experiences of service. Through critical reflection on theoretical texts and experiential learning, service-learning students must (and in many ways, already do) question how identity and identification are influenced and made by investment in the service experience as an academic text. The experience of service can be understood as a text in this case in that it is a theoretically rich, academic "work" (or set of works) valued for its content and brought into conversation with other works. In the experience of learning through queer or servicelearning methods, students are consistently faced with the knowledge that their identifications of selfhood and readings of texts/experiences are in flux, mediated, and transformed by their learning process — indeed, for Britzman (1995), "reading practices might well read all categories as unstable, all experiences as constructed, all reality as having to be imagined, all knowledge as provoking uncertainties, misrecognitions, ignorance, and silences" (p. 164). Theories of queer pedagogy prompt learners to contend with the ways in which they are being fundamentally transformed through the reading process, or becoming implicated in knowledge. Given the strong connection between service-learning theory and queer pedagogy, the idea of reading texts and experiences as "provoking a dialogue" (Britzman, 1995, p. 163) should be used to inform the structure of community service-learning courses: where instructors encourage individual reflection and inquiry, so too should they facilitate community inquiry of 
texts. Because most service-learning courses place students in situations in which their analysis of the service-learning text is a communal one (in that the features of the text come out of interactions with community members, classmates partners, etc.), reflecting on and analyzing these texts in a community environment (such as the classroom) allows for a richer, deeper engagement with both experiential as well as theoretical texts. ${ }^{1}$

In a similar vein, the emphasis on reflection present in both community service-learning and queer pedagogy lends itself strongly to archiving. While queer theory has established a theoretical archive and canon, community service-learning, as a younger field, has not yet done so to the same extent. In order to strengthen and diversify community service-learning as a movement and method, techniques of archiving and dialogical reflection should be borrowed from queer theory as a successful revolutionary movement in academic thought. Where queer theory embraces storytelling and reflection as not only valuable, but also academic and theoretical, so too should CSL understand its reflective works (including reflective journal writing and other student-produced works of casual, non-graded reflection) as worthy not only of use within the course, but also of archiving. Such archiving would prevent instructors and learners from repeatedly "reinventing the wheel," provide a temporality and evolution of thought to the discipline as a whole, and allow dialogical engagement with the work of others. While several Canadian universities have chosen to use student-created e-portfolios as double-duty archiving/reflective projects (Taylor et al., 2014; University of Ottawa, 2014), the lack of dialogical engagement and critical reading among students, low degree of theoretical legitimation, and relative obscurity and low-traffic of e-portfolio web pages means that even intellectual breakthroughs rarely last beyond the timeline of a semestered class or service placement. In other words, reflective works such as portfolios or journals often serve as a framework for community service-learning courses, but (from experience writing, reading, and researching these works) they rarely receive the focused, rigorous attention and analysis they warrant. A possible solution to this disconnect lies in the archiving of discourses present in queer theory circles; by valorizing high-quality reflective and creative works as legitimately academic, queer theory has established an archive whose structure mirrors its principal theoretical underpinnings.

\section{Problems \& Prospects}

Overall, there is a strong, consistent connection between the goals and effects of community service-learning and queer pedagogy. As a result, existing bodies of queer theory and queer pedagogy can inform, enhance, and deepen understandings of the value of service-learning in academic and theoretical contexts. Explicating queer pedagogy as a methodological study of limits, ignorance, and reading practices allows these connections to become more visible, and the experience of community service-learning can become grounded in a theoretical language that speaks to the specific struggles and features of the service-learning experience. As a study

\footnotetext{
${ }^{1}$ As an example of community inquiry of texts, see Philosophy for Children/Engaged Inquiry literature: Barrow, 2015; Johnson, 1984; Lipman \& Sharp, 1978; Topping \& Trickey, 2014.
} 
of limits, queer pedagogy is shown to bring light to "what we cannot bear to know," particularly in the case of community service-learning, the unthinkability of our own privilege and our own roles as propagators of privilege and cultural normalcy. As the study of ignorance, queer pedagogy mirrors service-learning through its acknowledgement that there can be a disconnect between conceptions of truth and claims to objectivity or neutrality, as well as the enactment of good conduct through good information. By claiming ambiguity, contention, and an agitated, long-form learning process as sites of productivity in theory, queer/service-learning pedagogies distinguish themselves from other modes of thought but draw a connection to one another. Finally, as a study of reading practices, queer theory understands reading as dialogical, reflective, and transformative — a step which service-learning has, in some ways, embodied in its pedagogical practice, but from which it can continue to develop a dynamic, complex, appropriately "queer" system of teaching and learning.

\section{About the Author}

Jordan Sifeldeen has a Bachelor's degree in Sociology with a minor in Women's and Gender Studies. He has great interest in the role of community building and dialogue in education. For his ability to explore these channels, he greatly credits Eurekamp, Philosophy for Children Alberta, and the continued mentorship of Dr. Jason Taylor. Email: jsifelde@ualberta.ca

\section{References}

Barrow, W. (2015). 'I think she's learnt how to sort of let the class speak': Children's perspectives on Philosophy for Children as participatory pedagogy. Thinking Skills and Creativity, 17, 76-87. doi:10.1016/j.tsc.2015.06.003

Berlant, L., Warner, M., Clarke, E., Denisoff, D., Hainley, B., Hoad, N.,...Woodhouse, R. (1994). FORUM: On the political implications of using the term 'Queer,' as in 'Queer Politics,' 'Queer Studies,' and 'Queer Pedagogy'. The Radical Teacher, 45, 52-57.

Britzman, D. P. (1995). Is there a queer pedagogy? Or, stop reading straight. Educational Theory, 45, 151-165.

Butin, D. W. (2010). Service learning in theory and practice: The future of community engagement in higher education. New York, NY: Palgrave MacMillan.

Dunlap, M., Scoggin, J., Green, P., \& Davi, A. (2007). White students' experiences of privilege and socioeconomic disparities: Toward a theoretical model. Michigan Journal of Community Service Learning, 13(2), 19-30.

Engaged Scholar Journal: Community-Engaged Research, Teaching, and Learning 
Hall, D. E. (2007). Cluelessness and the Queer classroom. Pedagogy, 7(2), 182-190.

Himley, M. (2004). Facing (up to) "The Stranger" in community service learning. College Composition and Communication, 55(3), 416-438.

Johnson, T. W. (1984). Philosophy for children: an approach to critical thinking. Bloomington, IN: Phi Delta Kappa Educational Foundation.

Jones, S. R. (2003). The underside of service-learning. About Campus, 7(4), 10-15.

Kirk, A. (2008). Embracing ambiguity in a critical/Queer pedagogy. Kaleidoscope: A Graduate Journal of Qualitative Communication Research, 7.

Lipman, M., \& Sharp, A. M. (1978). Growing up with philosophy. Philadelphia, PA: Temple University Press.

Luhmann, S. (1998). Queering/querying pedagogy? Or, pedagogy is a pretty queer thing. In W. F. Pinar (Ed.), Queer theory in education (pp. 141-155). Mahwah, NJ: Laurence Erlbaum Associates Publishers.

McIntosh, P. (1988). White privilege and male privilege: A personal account of coming to see correspondences through work in Women's Studies. Wellesley College Center for Research on Women, 1-20.

Queen's University. (2014). Community service learning.

Rutherford, J. (1990). A place called home: Identity and the cultural politics of difference. In J. Rutherford (Ed.), Identity: Community, culture, difference (pp. 9-27). London, England: Lawrence and Wishart Limited.

Smith, K. (2013). Decolonizing Queer pedagogy. Affilia: Journal of Women and Social Work, 28(4), 468470.

Taylor, A., Clandinin, J., White, J., Kahlke, R., Hamm, Z., \& Simpson, J. (2014). CSL working paper series 1: Thinking about student reflection across disciplines.

Topping, K., \& Trickey, S. (2014). The role of dialog in philosophy for children. International Journal of Educational Research, 63, 69-78. doi:10.1016/j.ijer.2013.01.002

University of Alberta CSL House. (n.d.) Why CSL?

University of Ottawa. (2014). Society, The Individual, and Medicine: Community Service Learning (CSL).

Whitlock, R. U. (2010). Getting Queer: Teacher education, Gender Studies, and the cross-disciplinary quest for Queer pedagogies. Issues in Teacher Education, 19(2), 81-103. 